DOI: 10.34015/2523-4552.2021.3.08

УДК 340.155:343.8

Власенко C. I., кандидат юридичних наук, доцент, доцент кафедри історії держави і права України і зарубіжних країн Національного юридичного університету імені Ярослава Мудрого ORCID: 0000-0001-7696-6096

\title{
ПЕНІТЕНЦІАРНІ ІДЕЇ АНГЛІЙСЬКИХ ПРОСВІТНИКІВ: ВІЛЬЯМА ПЕЙЛІ ТА САМУЕЛЯ РОМІЛЛІ
}

У статті визначено й проаналізовано ідеї та погляди представників англійського просвітництва Вільяма Пейлі та Самуеля Роміллі на реформу карної політики, мету й систему покарань, визначено місце тюремного ув'язнення та режимних засад його реалізації у концепціях зазначених авторів.

Ключові слова: Вільям Пейлі; Самуель Роміллі; Просвітництво; система покарань; режим утримання засуджених.

В статье определены и проанализированы идеи и взгляды представителей английского просвещения Уильяма Пейли и Сэмюэля Ромилли на реформу уголовной политики, цели и систему наказаний, определено место тюремного заключения и режимных основ его реализации в концепциях указанных авторов.

Ключевые слова: Уильям Пейли; Сэмюэль Ромилли; Просвещение; система наказаний; режим содержания осужденных.

Постановка проблеми. Дискусії навколо перегляду чинної системи покарань з урахуванням як засад національної правової традиції, так і досвіду європейських країн [1], а також триваюча реформа сфери виконання покарань актуалізують дослідження ідей філософів і правників, на яких грунтується зарубіжна пенологія.

Постановка завдання: визначити й проаналізувати ідеї та погляди Вільяма Пейлі та Самуеля Роміллі на реформу карної політики, мету й систему покарань, визначити місце тюремного ув'язнення та його режи- мних засад у концепціях зазначених авторів.

Аналіз останніх досліджень та публікацій. $\mathrm{y}$ британській історіографії політико-правові погляди В. Пейлі та С. Роміллі традиційно розглядалися у межах досліджень руху за гуманізацію пенальної політики та перегляд Кривавих кодексів (М.Ф.Конлі, К. Філліпсон, Л. Радзіновіч, К. Кенні та ін.) [2; 3; 4; 5]. В останні роки простежується певний дослідницький інтерес до пенітенціарної проблематики у фундаментальних роботах цих просвітників, свідченням чого $\epsilon$ статті 
російських авторів, зокрема С. Васильєвої [6] та О. Родіонова [7].

Виклад основного матеріалу.

Епоха Просвітництва відрізнялася новою світоглядною концепцією, згідно з якою, увага почала звертатися на людину, її потреби, права та свободи. Одними з яскравих представників англійського Просвітництва були Вільям Пейлі (William Paley) та Самуель Роміллі (Samuel Romilly), відомі прогресивними гуманістичними поглядами на систему покарання. I хоча їх позиції доволі різнилися, усе ж трансформація політико-правової думки щодо найбільш доцільних засобів боротьби зі злочинністю найкраще може бути простежена на прикладі поглядів саме цих просвітників, які поступаються за популярністю більш знаним у нас тюремним реформаторам, зокрема Дж. Говарду, Дж. Бентаму, Е. Фрай та ін.

Філософські погляди Вільяма Пейлі сформувалися на межі християнського консерватизму та утилітаризму. Одна з найвідоміших його робіт Принципи моральної і політичної філософії, що побачила світ 1785 року. В її основі лекції, які читав В. Пейлі з моральної філософії в коледжі Христа в Кембриджі. Цитована під час парламентських дебатів, залишаючись у програмі Кембриджа до $\mathrm{XX}$ ст., ця робота стала одним із найвпливовіших текстів у Британії доби Просвітництва. Ортодоксальний богослов, грунтуючи свою утилітарну етику на релігійній складові, В. Пейлі дотримувався прогресивних поглядів на питання толерантності та работоргівлі.

Дослідники-правники акцентують на суперечливості поглядів В. Пейлі на правову систему Англії.
М. Ф. Конлі ілюструє це на прикладі аналогії, що її використав сам автор. Так, він описував правову систему, порівнюючи її зі старим будинком, який був перебудований і доповнений з огляду на потреби мешканців упродовж кількох поколінь. Автор визнавав, що ці переобладнання не мали ні плану, ні загальної чіткої мети, і для стороннього спостерігача, скоріш за все, виглядали незрозуміло й безглуздо. Але це не суттєво, оскільки вони влаштовували мешканців. Таким чином, англійська правова система попри її вади, писав В. Пейлі, підходить людям, як і будинок мешканцям. Якщо вдаватися до такого порівняння, зазначав М.Ф.Конлі, то заради справедливості необхідно вказати, що під час перебудови будинку, зайві, застарілі речі все ж таки викидають, натомість в англійському праві все залишалося, незалежно від того «було воно придатне до використання чи ні» $[2,18]$.

Попри те, що В. Пейлі частіше фігурує в історіографії як шанобливий захисник Кривавого кодексу, але навіть він визнав несправедливість смертної кари щодо кишенькових злодіїв, з усім авторитетом відстоюючи тезу про доцільність у випадках незначних правопорушень заміни шибениці й транспортації ув'язненням у пенітенціарному будинку $[8,88]$.

Ядром правової думки В. Пейлі $\epsilon$ утилітаристське вчення про моральність, яке він поклав в основу уявлень про покарання та його мету. у покаранні він вбачав перш за все не кару за вчинення злочину, а його попередження. Розмірковуючи про «гуманне покарання», В. Пейлі вказував, що його ціль - це не відплата, а превенція $[9,300]$. Він був упевне- 
ний, що вимога правосуддя карати це не мотив гуманного покарання, а от імовірність того, що приклад ухилення злочинця від належної відплати заохочує його або інших осіб вчинити подібний злочин уже $є$ визначальним мотивом для застосування гуманного по своїй суті покарання.

У подальшому філософ зазначав, що справжня причина і мета покарання, безсумнівно, $€$ мірилом жорстокості відплати, але власне ця причина лежить не у винності 3лочинця, а в необхідності превенції злочинів, що готуються. Тобто покарання не повинно бути жорстоким в тому випадку, якщо злочин може бути попереджений іншим способом.

Торкаючись загальних питань призначення і виконання покарання, В. Пейлі стверджував, що покарання переслідує дві мети - виправлення і демонстрацію, причому першу мету він вважав більш практичною, але безумовно менш ефективною. 3 усіх покарань для досягнення мети виправлення найбільш випробуваним і надійним, на його думку, $\epsilon$ позбавлення волі у виді тюремного ув'язнення. Він писав, що ці заходи збільшують страхітливий ефект покарання, ізолюють злочинця від суспільства із собі подібними ... і в засудженого відбуваються зміни в поведінці $[9,302]$.

Значну увагу філософ приділив питанню одиночного утримання під час відбування покарання. Загалом самотність він вважав найбільш підходящим станом для єднання 3 Богом, у якому й проявляється свобода природнього стану. Саме одиночне утримання злочинців, коли вони ізолюються від товаришів по «ремеслу», сприятиме їх виправленню (реформації) і не дозволить поширюватися злочинним нахилам. У таких умовах злочинець переконається у хибності його вибору й відчує каяття, що, неодмінно, позначиться на його поведінці [9, 349, 543-544].

Вільям Пейлі одним з перших обгрунтував думку про доцільність використання фізичної праці засуджених в цілях досягнення виправного ефекту. Зокрема, він вказував на те, що антипатія до праці $є$ причиною половини людських вад, вона $€$ чинником, що породжує і посилює це зло навіть у пересічної особистості. Саме тому потрібно надавати можливість засудженим працювати в нормальних умовах, а не знищувати їх за допомогою тяжкої фізичної роботи впродовж всього періоду виконання покарання, що аж ніяк не буде сприяти виправленню.

У своїй роботі В. Пейлі вказував, що рівень страхітливого ефекту покарання має бути прямопропорційним загрозі, яку може в майбутньому завдати злочинець суспільству. Тому, не зважаючи на гуманізм, він виступав за смертну кару, яку вважав найефективнішим видом застереження інших від вчинення злочинів.

Філософ виділяв два методи відправлення кримінального правосуддя при призначенні смертної кари. Перший метод полягає в регулярному застосуванні смертної кари, але за незначне число суворо визначених видів злочинів. При другому методі необхідно призначати смертну кару за широке коло злочинів, але виконувати в невеликій демонстративній кількості щодо кожного 3 діянь визначеної групи.

Розглядаючи необхідність призначення смертної кари в Англії, філософ виділяв три основні причи- 
ни: існування занадто багато свободи; проживання у великих містах; недостатність покарань, які не супроводжувалися смертю і при цьому були достатніми для залякування. У цьому випадку В. Пейлі відкидав концепцію реабілітації і стверджував, що в більшості випадків смертна кара робить злочинця краще, ніж він був, тоді як в'язниця легко перетворює злочинця-новачка в людину з глибокими кримінальними нахилами.

Особливого значення він надавав діяльності органів правосуддя 3 винесення ними справедливих покарань, що, зокрема, стосувалося ретельного встановлення судами всіх обставин справи, ролі судів у превенції злочинів за допомогою винесення ними адекватних, але разом 3 тим гуманних санкцій. Не менш цікавим $є$ його підхід до деяких обставин вчинення злочинних діянь. Так, В. Пейлі говорив, що від ступеня тяжкості вчиненого злочину залежить вид призначеного покарання: легкість злочину повинно відтягувати покарання.

При всій прагматичності його поглядів на покарання, В. Пейлі був прихильником прогресивногуманістичних ідей. Важливо відзначити, що він одним з перших звернув увагу на турботу за особами, звільненими з місць відбування покарання. Також він наполягав на тому, що обов'язком держави $\epsilon$ забезпечення звільнених осіб роботою і, що є більш важливим - їх подальше відокремлення від тих осіб, які не бажають чесно трудитися.

Ідеї В. Пейлі стосовно призначення покарання, необхідності залучення злочинців до праці задля реабілітації та подальшого повернення до суспільства, ролі держави та дер- жавних органів влади у попередженні злочинів та ресоціалізації злочинців у свій час вирізнялися прогресивністю, що в подальшому й призвело до їх поступового впровадження в пенітенціарну практику. Його погляди стали основою для наукового пошуку в напрямку розвитку пенітенціарної ідеї про покарання і реформ в цій галузі.

Публікація основних філософсько-теологічних праць В.Пейлі співпала з активним рухом за перегляд системи покарань, у частині їі гуманізації, та покращення устрою в'язниць. У результаті зусиль філантропів і законотворців у Британії упродовж 1775-1789 pр. було ухвалено низку законів, що упроваджували нагляд за в'язницями, обов'язкові візити до в'язниці капеланів та лікарів тощо. На рівні графств було реалізовано в'язничну реформу, а саме перебудовано виправі будинки та в'язниці, відповідно до рекомендацій філантропів, зокрема Дж. Говард. Однак радикальної зміни системи покарань у цей період не відбулося. Де-юре продовжувало діяти «криваве законодавство», відповідно до якого смертна кара передбачалася більше ніж за 200 складів злочинів.

3 огляду на європейський гуманістичний рух і скасування на континенті в окремих країнах (зокрема в Тоскані) смертної кари під впливом прогресивних ідей Ч. Беккаріа, у Британії на парламентських слуханнях повсякчас поставало питання реформування системи покарань. Саме завдяки пристрасним промовам члена Палати громад С. Роміллі питання лібералізації кримінальних законів набули особливої актуальності. 
Погляди С. Роміллі щодо виконання покарань уперше викладені у критичному нарисі роботи Мартіна Мадана Роздуми про реалізацію правосуддя 1786 р. С. Роміллі, вбачаючи в причинах злочинності насамперед соціальне коріння та пороки суспільства, вважав, що адекватне злочину покарання діє як безумовний засіб утримання від його повторного вчинення і служить меті загальної превенції [10]. Разом з тим, враховуючи фактор «людських недоліків», тобто природні вади й потенційну схильність людей до здійснення асоціальних вчинків, філантроп вказував, що діяння може вважатись злочинним лише у разі абсолютної доведеності, і тільки в цьому випадку має слідувати справедливе покарання. В результаті в аналізованій роботі він наполягав на обов'язковому перевихованні осіб, які, по суті, стали жертвами соціальних деформацій. При цьому одиночне ув'язнення і фізична праця, на його погляд, були необхідним засобом такого перевиховання.

31808 р. С. Роміллі активно долучився до руху за гуманізацію покарань, зокрема зменшення складів злочинів, що передбачали покарання у виді смертної кари. Він зазначав, що «право нашої країни, дійсно, написано кров'ю» $[11$, с. 279]. На думку просвітника, смертна кара не відповідала самій сутності кримінального покарання, яке повинно бути спрямовано, окрім превенції і залякування, на виправлення злочинця.

Як видається, С. Роміллі вперше 3 науково-теоретичних позицій продемонстровано взаємозв'язок між зростанням злочинності й надмірною жорстокістю покарань. 3 цієї причини, задля зменшення злочин- ності та іiї превенції, він пропонував звернути увагу на поліпшення умов утримання засуджених в тюремних закладах та вдосконалення засобів і методів виправлення засуджених. С. Роміллі доводив можливість перевиховання навіть найбільш закоренілих злочинців, які вчинили тяжкі злочини, і заперечував тезу про їх принципову неспроможність виправлення. Єдине, коли на думку аболіціоніста можливе застосування вищої міри покарання - це вчинення посягання на життя людини, втеча 3 в'язниці або вчинення нового тяжкого злочину в період відбування покарання. Реформатором проголошувався принцип, відповідно до якого метою кримінального покарання має в першу чергу виступати виправлення злочинця.

1811 року С. Роміллі запропонував створити спеціальну парламентську комісію з вивчення тюремного питання і повернутися до ідеї зведення пенітенціарних будинків для утримання злочинців, яких присуджено до транспортації, як це передбачав Пенітенціарний акт 1779 p. Він критично ставився до вигнання (тарнспортації), вказуючи на його неефективність. Проєкт відправки засуджених в Австралію С. Роміллі називав безглуздим, такі особи назавжди будуть втрачені для держави, оскільки для більшості 3 них заслання фактично стане пожиттєвим, вони не зможуть повернутися на батьківщину. Для каторжних робіт і колонізації Австралії, на думку реформатора, слід було б обирати засуджених 3 регіонів, обізнаних 3 сільського господарською працею, а не злочинців зі столиці та графства Мідлсекс, як це пропонувалося у проєкті. 
Систему утримання осіб, засуджених до транспортації, у плавучих тюрмах, упроваджених через неможливість їх відправки до Північно-Американських колоній, С. Роміллі теж вважав хибною. Злочинці там перебували у жахливих умовах, разом утримувалися різні категорії засуджених. Якщо неповнолітні потрапляли туди новачками то після перебування у товаристві засуджених, виходили на свободу уже запеклими злодіями.

Необхідними складовими реформи в'язниць С. Роміллі називав розділення різних категорій ув'язнених за статтю, віком, вчиненими злочинами, окреме утримання підслідних та засуджених, покращення санітарних умов утримання, встановлення нагляду за діяльністю тюремної адміністрації. Одиночне ув'язнення С. Роміллі вважав формою покарання гіршою за смерть, що призводить лише до відчаю та безумства, спричиняючи нелюдські страждання, і був проти утримання в одиночній камері навіть у якості короткострокового дисциплінарного заходу щодо порушників дисципліни у робітних будинках [3, 315-316].

Слід також відзначити, що С. Роміллі фактично був основоположником учення про обставини, що пом'якшують і обтяжують покарання, теорії загальних засад призначення покарання в англійському кримінальному праві. Ним відзначався постулат про те, що одна і та ж обставина може розглядатися судом як така, що пом'якшує і як така, що підсилює покарання: легкість вчинення злочину, його повторність, юний вік злочинця, який, зокрема, може вказувати, з одного боку, на те, що злочинець ще не є закоренілим, 3 іншого - на те, що він передчасно розбестився. Проблема обліку даних обставин мала велике значення для досягнення цілей покарання.

Відомий англійський дослідник К. Кенні вказував, що С. Роміллі здобув заслужену славу завдяки своїм успішним зусиллям очистити середньовічне кримінальне право від безцільної жорстокості за допомогою скасування покарань, що калічать засуджених, зменшення випадків застосування смертної кари й переобладнання тюрем [5, 582-583]. На тлі досягнень С. Роміллі в розробці вчення про обставини, що пом'якшують і обтяжують покарання, теорії загальних засад призначення покарання К. Кенні зазначає, що до XIX ст. проблема виправлення злочинців була недооцінена, так як людські вчинки, окрім деяких винятків, пояснювалися 3 позиції рівності моральної відповідальності. Тому не зовсім правильно було вважати, «що якщо покарання вибрано вдало, загроза його застосування буде дієво утримувати нормальних людей від вчинення злочинів». Проте існування великої кількості «рецидивістів» засвідчило, наскільки перебільшені були надії, які колись покладалися на виправлення як основну мету покарання. К. Кенні робить слушний висновок, що «злочинність зменшилась не стільки тому, що люди стали більше боятися жахів покарання, скільки тому, що вони змогли піднятися над спокусою скоїти злочин» [5, 582-583].

Самуеля Роміллі можна вважати одним із засновників теоретичної концепції соціальної превенції злочинності як основної мети гуманізації покарань, яку він досить 
структурно виклав у Зауваженнях 3 кримінального права Англї щодо покарання смертною карою і порядку ї застосування 1810 р. [12].

Висновки. В. Пейлі та С. Роміллі були видатними представниками англійського реформаторського руху, спрямованого на лібералізацію й гуманізацію державних репресій, а також раціональне застосування засобів державного при- мусу. Завдяки теоретичним роботам просвітників ідея виправлення в теорії покарання набула більш чітких рис i практичної спрямованості. Їм вдалося наповнити поняття покарання елементами, що відбивають його соціальний зміст, і тим самим пов'язати його $з$ проблемами суспільного розвитку, кримінальної політики держави і станом тюрем.

\section{Список використаних джерел}

1. Концепція реформування кримінального законодавства України. URL: https://newcriminalcode.org.ua/concept (дата звернення: 10.10.2021).

2. Conley, Martin Francis (1957). The Criminal Law Reforms of Sir Samuel Romilly. A Thesis Submitted to the Faculty of the Graduate School ot of Loyola University in Partial Fulfillment of the Requirements for the Degree or Master of Arts.

3. Phillipson, Coleman (1923). Three Criminal Law Reformers: Beccaria, Bentham, Romilly. J. M. Dent \& Sons.

4. Radzinowicz, Leon (1948). A History of English Criminal Law and its Administration from 1750: The Movement For Reform 1750-1833. New York: Macmillan, 1.

5. Кенни, К. (1949). Основы уголовного права; под ред. Б. С. Никифорова, пер. с англ. В. И. Каминской. Москва : Изд-во иностранной лит-ры [Kenny, С. (1947). Outlines of Criminal Law].

6. Васильева, С. А. (2015). К вопросу о формировании гуманистических основ пенитенциарной педагогики. Прикладная юридическая психология [Vasileva, S. A. (2015)/ K voprosu o formirovanii gumanisticheskih osnov penitenciarnoj pedagogiki. Prikladnaya yuridicheskaya psihologiya], (3), 106-111.

7. Родионов, А. В. (2017). Организация труда осужденных в Великобритании в XIX в. - середине XX в. (историко-правовой аспект). Вестник Кузбасского института [Rodionov, A. V. (2017). Organizaciya truda osuzhdennyh v Velikobritanii v XIX v. - seredine XX v. (istoriko-pravovoj aspekt). Vestnik Kuzbasskogo instituta], 3 (32), 148-152.

8. Ignatieff, M. (1978). A Just Measure of Pain : the Penitentiary in the Industrial Revolution, 1750-1850. New York : Pantheon Books.

9. Paley, W. (1785). The Principles of Moral and Political Philosophy. London, R. Faulder.

10. Romilly, Samuel (1786). Observations on a late publication, intituled, Thoughts on executive justice: to which is added, a letter containing remarks on the same work. London : sold by T. Cadell, in the Strand; and R. Faulder, in new Bond Street.

11. Memories of the Life of Sir Samuel Romilly, written by himself; with a selection from his Correspondence / Edited by his sons. In Three Volumes. Vol. I. $2^{\text {nd }}$ ed. London : John Murray, Albemarle Street., 1840.

12. Romilly, S. (1810). Observations on the Criminal Law of England, as it relates to capital punishments, and on the mode in which it is administered. London : T. Cadell and W. Davies, 1810. 
S. Vlasenko, PhD in law, Docent, Associate Professor in the Department of History of State and Law of Ukraine and Foreign Countries, Yaroslav the Wise National University of Law Honored Lawyer of Ukraine

ORCID: 0000-0001-7696-6096

\section{The penitentiary ideas of the English Enlighteners: William Paley and Samuel Romilly}

The article identifies and analyzes the ideas and views of English educators William Paley and Samuel Romilly on penal policy reform, the goals and system of punishment, defines the place of imprisonment and the regime foundations of its implementation in the concepts of these authors.

Paley's ideas on sentencing, the need to attract criminals to work for rehabilitation and further return to society, the role of the state and public authorities in crime prevention and resocialization of criminals at one time were progressive, which later led to their gradual introduction into prison practice. His views became the basis for scientific research in the direction of the penitentiary idea of punishment and reform in this area.

Samuel Romilli can be considered one of the founders of the theoretical concept of social crime prevention as the main goal of humanizing punishment. Through the theoretical works of the Enlighteners, the idea of correction in the theory of punishment acquired clearer features and practical orientation. They managed to fill the concept of punishment with elements reflecting its social content and thereby link it to the problems of social development, state criminal policy and the state of prisons.

Keywords: William Paley; Samuel Romilly; Enlightenment; penal system; prison regime. 